\title{
Voltinism and larval growth pattern in Coenagrion mercuriale (Odonata: Coenagrionidae) at its northern range margin
}

\author{
BETHAN V. PURSE and DAVID J. THOMPSON \\ Population and Evolutionary Biology Research Group, University of Liverpool, Nicholson Building, School of Biological Sciences, \\ PO Box 147, Liverpool, L69 3GS, UK; e-mail: bvpurse@liverpool.ac.uk
}

Keywords. Odonata, Coenagrion mercuriale, Pyrrhosoma nymphula, seasonal regulation, diapause,voltinism, larval growth, intraspecific predation

\begin{abstract}
Voltinism and larval growth pattern were investigated in an edge-of-range population of Coenagrion mercuriale. Coenagrion mercuriale is semi-voltine in Britain and growth is inhibited in winter. The $2^{\text {nd }}$ year group overwinters in a range of instars between the antepenultimate and final instar consistent with the early, asynchronous emergence pattern of this species. A facultative autumnal diapause in the penultimate instar is the most likely mode of seasonal regulation. The broad size distribution of larvae produced by this growth pattern was wider than that found in co-occurring populations of Pyrrhosoma nymphula, a "spring" species with synchronous emergence. The broad size distributions may lead to considerable intraspecific interference between $C$. mercuriale larvae. Sex ratio in the last three larval instars of $C$. mercuriale did not differ significantly from unity. A laboratory investigation of the effect of temperature and photoperiod on growth and diapause in C. mercuriale is recommended to determine whether high minimum temperature thresholds for development limit both the width of the temporal niche and microhabitat use by this species at its range margin.
\end{abstract}

\section{INTRODUCTION}

The significance of developmental polymorphism in conservation biology is that survival depends on the optimal survival of all developmental stages (Samways, 1994). For rare species of Odonata, with an aquatic larval stage and a terrestrial adult stage (Corbet, 1980), baseline information on all developmental stages is required for formulation of adequate management policy.

Coenagrion mercuriale has a southwestern distribution in Europe and reaches its northern range margin in Britain. It has declined particularly in countries along the northern and eastern boundaries of its distribution (Grand, 1996). In Britain, it is listed as rare (category 3) on the red list and is the subject of a UK Biodiversity Action Plan (HMSO, 1995). In this paper, voltinism and larval growth pattern in the aquatic stage of $C$. mercuriale in Britain are investigated and compared with the growth pattern found in mainland European populations.

Such a comparison is pertinent because dragonflies are thermophilic (Krishnaraj \& Pritchard, 1995; Sternberg, 1994) and their development, seasonality, distribution and habitat use are likely to be strongly restricted by temperature (May, 1978). In other thermophilic insect taxa, such as Lepidoptera, species often occupy narrower niches within biotopes towards the edges of their ranges (Thomas et al., 1999).

The division of the life cycle into active and diapause stages has been crucial to the success of many temperatezone insects (Tauber et al., 1986). In odonates, seasonal regulation (i.e. the placement of adult emergence) is achieved by different diapause characteristics of the larvae, and distinct responses to critical day length and temperature thresholds in different instars (Corbet, 1957a;
Sternberg, 1994). In this paper, the location and possible mechanisms of diapause are examined in C. mercuriale and related to the asynchronous, late emergence observed in this species in Britain (Purse \& Thompson, submitted). Corbet (1957a) suggested that this type of emergence curve [typical of "summer" species (sensu Corbet, 1954)] could be produced by a rising series of lower temperature thresholds for entry into successive larval instars, ensuring that early instars are the first to resume growth in spring as the temperatures rise. Here, the existence in C. mercuriale of a facultative autumnal diapause in the penultimate instar is also investigated.

Consequences of the mode of seasonal regulation are examined including the size structure of the population and the sex ratio in the larval stage. The size structure of the larval population has implications for the type and intensity of population interactions (such as competition and predation) that may occur between different stages (Butler, 1984) and may affect habitat use by different instars. Operational sex ratios can determine which sex will compete for mates and the intensity of sexual competition (Kvarnemo \& Ahnesjo, 1996). Sex ratio has been widely examined at emergence in odonates (see review by Corbet \& Hoess, 1998) but not in the larval stage (but see Baker et al., 1992; Duffy, 1994; Garrison \& Hafernik, 1981; Lawton, 1972, Pickup et al., 1984).

\section{MATERIALS AND METHODS}

Larval sampling was carried out at three fixed sampling positions (1,2 and 3) on a 50m stretch of stream on the Glan-yr-afon Uchaf catchment (SN118345-SN118346, 52 latitude, - $5^{\circ}$ longitude) on Mynydd Preseli in Pembrokeshire, south Wales. The streams are shallow, narrow, spring-fed, runnels running through wet heath/soligenous valley mire with short stands of 


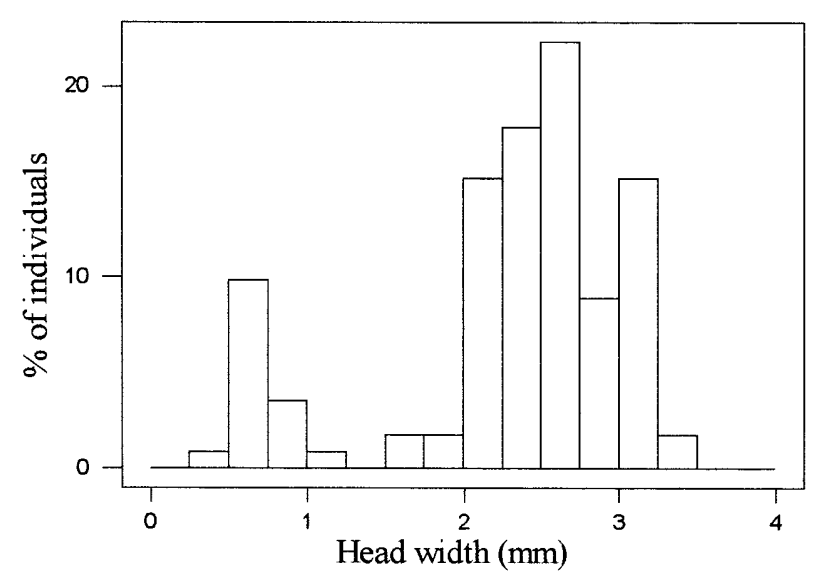

Fig. 1. Percentage of individuals in each head width class in October $(n=109)$.

heavily grazed gorse (Ulex gallii). At the sampling positions, emergent and marginal stream vegetation consisted mainly of Juncus sp. and Eleocharis palustris whilst submerged stream vegetation consisted mainly of Hypericum elodes, Potamogeton polygonifolius, Eleogiton fluitans, and Sphagnum spp. (including $S$. auriculum).

Given the small dimensions of the habitat and heterogeneous nature of macrophyte fauna in the Glan-yr-afon stream, pilot sampling with artificial substrates ( $c f$ Bennett \& Mill, 1993; Johannsson, 1978) and mechanical devices ( $c f$ Benke, 1970; Benke \& Bemke, 1975; Wissinger, 1988b) was unsuccessful Hand-netting of submerged vegetation was adopted as the sampling method since this yielded the full range of larval instars with minimum damage to the habitat. A standard net sweep was defined as the sweeping of a fine mesh $(1 \mathrm{~mm}$ mesh) pond net $(25 \mathrm{~cm}$ by $25 \mathrm{~cm}$ ) at a depth of $12.5 \mathrm{~cm}$ (half depth of net) up stream for a distance of $1 \mathrm{~m}$. A sample consisted of three such sweeps over the same $1 \mathrm{~m}$ stretch. The contents of the net were sorted in the field until all damselfly larvae had been removed (approximately 30 minutes). Each larva was placed in a $30 \mathrm{ml}$ tube with stream water and a perch and transported in a cool box to the laboratory. In the laboratory, head width, hind tibia length and wing bud length were measured under a binocular dissecting microscope using an eye-piece graticule calibrated with a slide micrometer. Larvae were returned to the stream positions within 5 days of collection.

On each sampling occasion, four samples were taken at positions 2 and 3 whilst two samples were taken at position 1. From October 1999 to September 2000, sampling was carried out at intervals ranging from 28 days to 53 days (mean interval $39.7 \pm$ 2.3 days). A shorter interval between samples was used during summer because larval growth was expected to take place more quickly at higher water temperatures.

Larvae of Pyrrhosoma nymphula were found in low numbers at the sampling positions but could be separated from $C$. mercuriale using the keys of Gardner \& MacNeill (1950), Carchini (1983) and Corbet (1955). In order to interpret life history and age structure of populations, it is necessary to assign individuals to instars or age categories using size or form characteristics (Baker, 1986). For clarity, 'instar' is used here to denote the interval between two successive ecdyses rather than "stadium" since the use of the former is more widespread. The use of $X-Y$ plots of two body measurements (rather than size-frequency histograms of one body dimension) produces clusters of points corresponding to instars, and has allowed their separation in several species of odonate (Banks, 1985; Edmonson \& Windberg, 1971; Pickup \& Thompson, 1984; Thompson, 1978b). For C. mercu-
TABLE 1. Mean ( \pm s.e.) head width, hind tibia length and wingbud length for instar groups of $C$. mercuriale.

\begin{tabular}{ccccc}
\hline $\begin{array}{c}\text { Instar } \\
\text { group }\end{array}$ & $n$ & $\begin{array}{c}\text { Mean head } \\
\text { width } \pm \text { s.e. } \\
(\mathrm{mm})\end{array}$ & $\begin{array}{c}\text { Mean tibia } \\
\text { length } \pm \text { s.e. } \\
(\mathrm{mm})\end{array}$ & $\begin{array}{c}\text { Mean wing bud } \\
\text { length } \pm \text { s.e. } \\
(\mathrm{mm})\end{array}$ \\
\hline A & 71 & $0.65 \pm 0.01$ & $0.60 \pm 0.01$ & - \\
B & 199 & $1.18 \pm 0.01$ & $0.96 \pm 0.01$ & $0.13 \pm 0.03$ \\
C & 351 & $1.78 \pm 0.01$ & $1.37 \pm 0.01$ & $0.56 \pm 0.02$ \\
D & 273 & $2.47 \pm 0.01$ & $1.81 \pm 0.01$ & $1.25 \pm 0.01$ \\
E & 214 & $2.99 \pm 0.01$ & $2.16 \pm 0.01$ & $2.09 \pm 0.02$ \\
F & 83 & $3.47 \pm 0.02$ & $2.48 \pm 0.02$ & $3.93 \pm 0.05$ \\
\hline
\end{tabular}

riale, 3-dimensional $\mathrm{X}-\mathrm{Y}-\mathrm{Z}$ plots (of head width, tibia length and wing bud length) and all combinations of $X-Y$ plots were used to check that clusters of individuals were consistent between body measurements. This process was carried out separately for males and females and for each month. Six instar groups (A-F) could be separated that were consistent between sexes, across months and across body dimensions. Group A corresponds to instars $2-6, \mathrm{~B}$ corresponds to instars $7-8, \mathrm{C}$ corresponds to instars 9-10 whilst $\mathrm{D}, \mathrm{E}$ and $\mathrm{F}$ corresponded to the antepenultimate, penultimate, and final instars respectively (see Corbet, 1955). For $P$. nymphula, such plots allowed separation of all 12 instars after the prolarva.

Since netting does not provide quantitative estimates of population levels (Downing, 1984), growth in the larval population was inferred from changes in the proportions of individuals in each instar group between consecutive months. For C. mercuriale, chi-squared tests were used to test for significant differences in these proportions between consecutive months (instars $\mathrm{A}$ and $\mathrm{B}$ were omitted since they were not detected consistently in samples), to determine when, in the year, growth of larvae occurred.

\section{RESULTS}

In ten monthly samples, 1195 larvae of $C$. mercuriale and 129 larvae of $P$. nymphula were collected. The percentage of $P$. nymphula ranged from $4-18 \%$ of a sample. The mean body dimensions of each instar group of $C$. mercuriale are shown in Table 1 and dimensions of each instar of $P$. nymphula are shown in Table 2.

\section{Voltinism in $C$. mercuriale}

Since eggs hatch without diapause (Corbet, 1955), the bimodal length-percentage histograms indicate that two years were required for larval development (i.e. semivoltine development) in C. mercuriale. (Fig. 1. shows the head width-percentage histogram for October). Each peak corresponds to a year group.

\section{Larval growth period}

Fig. 2 shows the percentage of individuals in each instar group in each month. Three larval cohorts were present in the samples. Cohort 1 hatched in 1998, was in instar groups D to $\mathrm{F}$ when sampling began in October 1999 and emerged in summer 2000. Cohort 2 hatched in 1999, was in instar groups A to C in October 1999 and would emerge in summer 2001. Cohort 3 hatched in summer 2000 (appearing first in June 2000) and would emerge in 2002. 
(a) $18 / 10 / 99 n=112$

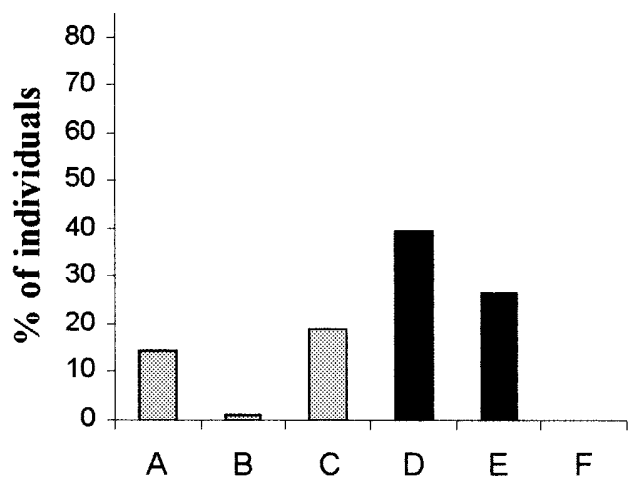

Instar group

(c) $12 / 01 / 00 \mathrm{n}=27$

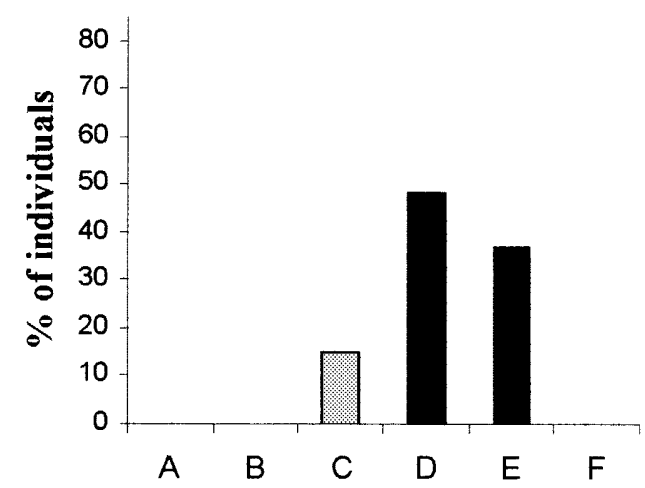

Instar group

(e) $29 / 03 / 00 n=93$

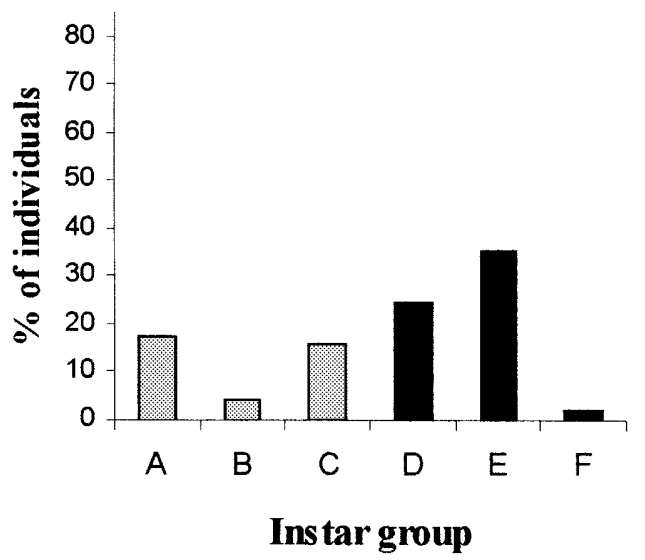

(b) $30 / 11 / 99 n=112$

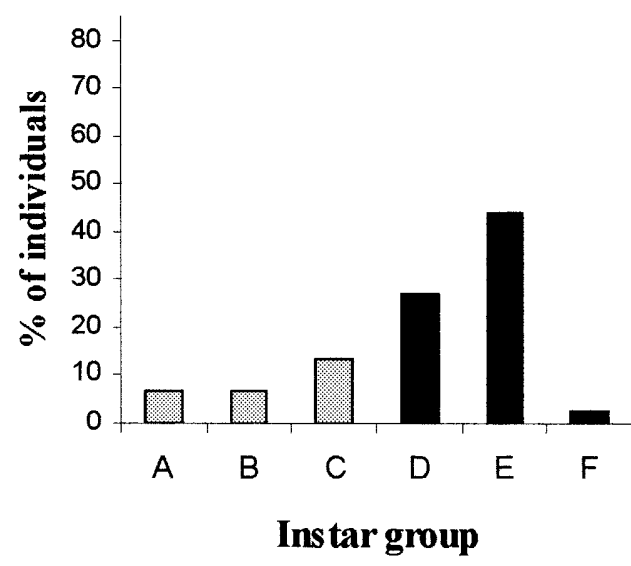

(d) $23 / 02 / 00 ~ n=87$

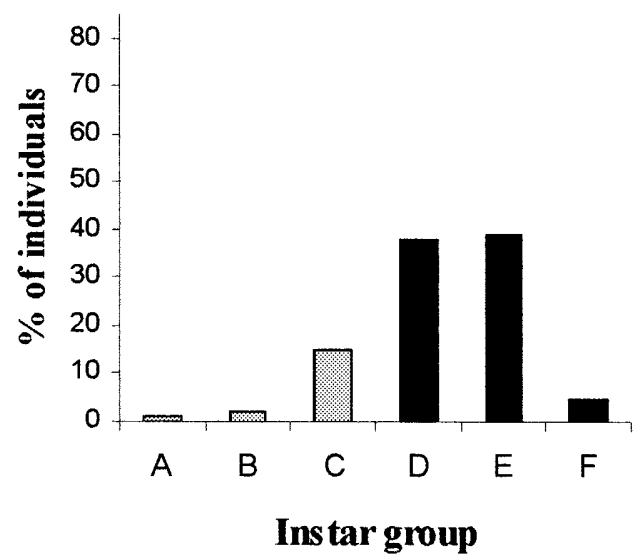

(f) $01 / 05 / 00 ~ n=103$

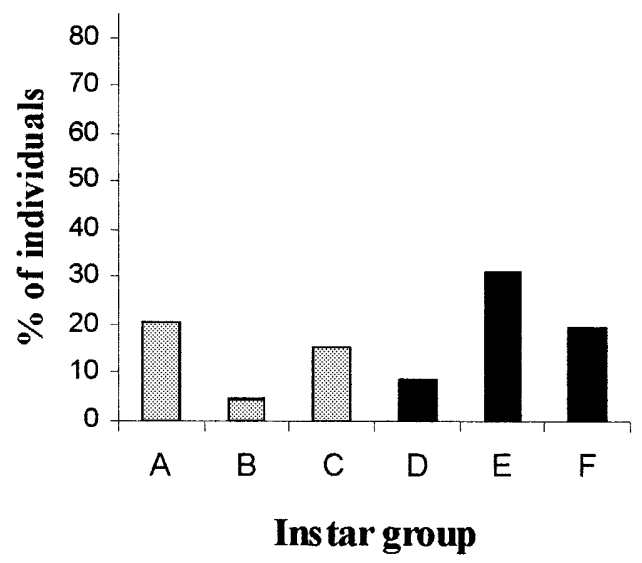

Fig. 2a-f. The percentage of individuals in each instar group. Cohort 1 (1998-2000) is represented by closed bars and Cohort 2 (1999-2001) by diagonally-striped bars.

Overall, there was no significant difference in instar proportions between consecutive months between November and March (Table 3). A large amount of growth occurred between March and August, as inferred from the magnitude of the chi-square value, and some growth also occurred in October and November. To locate diapause within each year group, the growth of each cohort is now examined separately.

Location of diapause in $C$. mercuriale

Second-year larvae in Cohort 1 overwintered (between October and March) in instar groups D (antepenultimate instar), $\mathrm{E}$ (penultimate instar) and $\mathrm{F}$ (final instar). The 
(g) $06 / 06 / 00 ~ n=71$

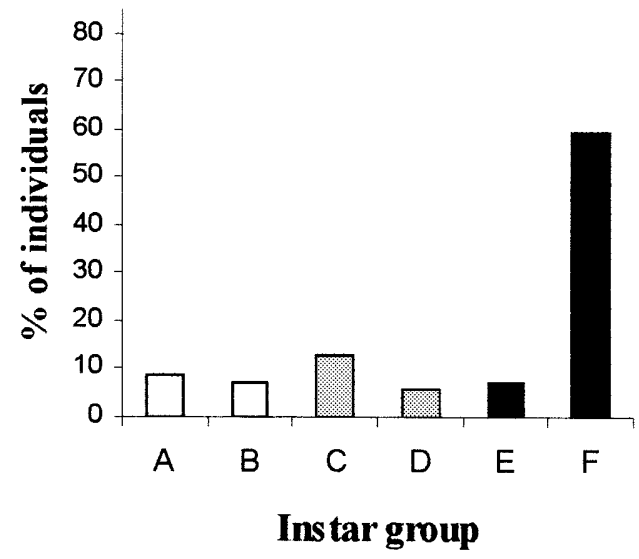

(i) $07 / 08 / 00 \mathrm{n}=247$

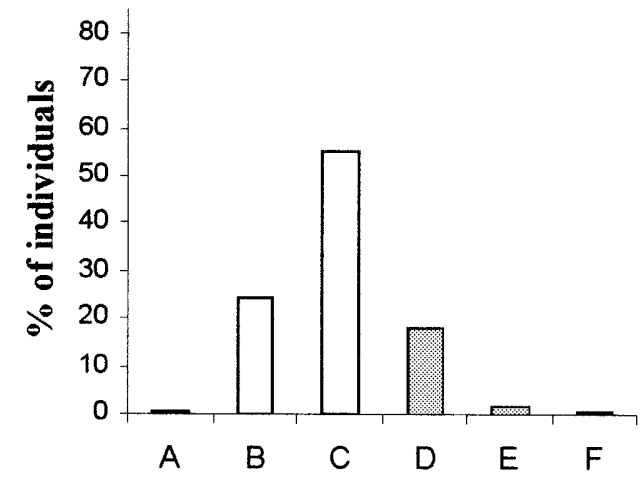

Ins tar group (h) $12 / 07 / 00 \mathrm{n}=167$

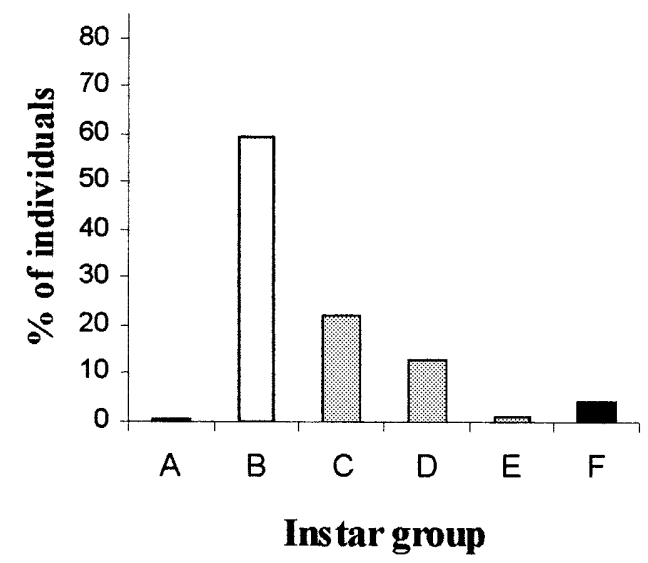

(j) $28 / 09 / 00 n=162$

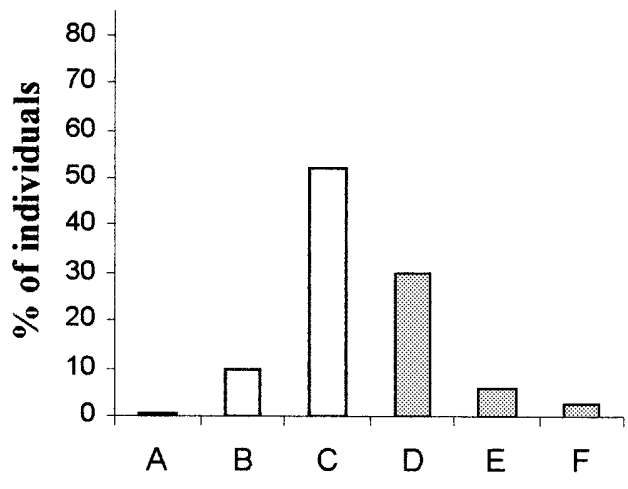

Instar group

Fig. 2g-j. The percentage of individuals in each instar group. Cohort 1 (1998-2000) is represented by closed bars, Cohort 2 (1999-2001) by diagonally-striped bars and Cohort 3 (2000-2002) by open bars.

percentage of individuals in $\mathrm{F}$ during this period, ranged from 0 to $4 \%$ of the cohort. The rest of the individuals were divided equally between instar groups $\mathrm{D}$ (mean $\%=$ $47.8 \pm 4.4$ ) and $\mathrm{E}($ mean $\%=49.7 \pm 3.7)$. Between March and May, individuals moved rapidly from instar groups D

TABLE 2. Mean, range and median of head width, hind tibia length and wingbud length for instars (excluding the prolarva) for $P$. nymphula.

\begin{tabular}{ccccc}
\hline Instar & $n$ & $\begin{array}{c}\text { Mean head } \\
\text { width } \pm \text { s.e. } \\
(\mathrm{mm})\end{array}$ & $\begin{array}{c}\text { Mean tibia } \\
\text { length } \pm \text { s.e. } \\
(\mathrm{mm})\end{array}$ & $\begin{array}{c}\text { Mean wing bud } \\
\text { length } \pm \text { s.e. } \\
(\mathrm{mm})\end{array}$ \\
\hline 2 & 3 & $0.53 \pm 0.00$ & $0.54 \pm 0.00$ & - \\
4 & 2 & $0.86 \pm 0.13$ & $0.81 \pm 0.02$ & - \\
5 & 6 & $1.19 \pm 0.03$ & $1.25 \pm 0.02$ & $0.26 \pm 0.15$ \\
6 & 3 & $1.33 \pm 0.04$ & $1.44 \pm 0.02$ & $0.28 \pm 0.05$ \\
7 & 15 & $1.61 \pm 0.02$ & $1.66 \pm 0.02$ & $0.38 \pm 0.02$ \\
8 & 16 & $1.91 \pm 0.02$ & $1.92 \pm 0.03$ & $0.68 \pm 0.03$ \\
9 & 5 & $2.14 \pm 0.03$ & $2.11 \pm 0.02$ & $0.81 \pm 0.10$ \\
10 & 27 & $2.40 \pm 0.02$ & $2.43 \pm 0.03$ & $1.26 \pm 0.04$ \\
11 & 17 & $2.96 \pm 0.03$ & $2.99 \pm 0.04$ & $2.24 \pm 0.03$ \\
12 & 4 & $3.60 \pm 0.03$ & $3.55 \pm 0.03$ & $4.16 \pm 0.46$ \\
13 & 2 & $4.11 \pm 0.34$ & $4.23 \pm 0.23$ & 5.07 \\
\hline
\end{tabular}

to $\mathrm{E}$ and from $\mathrm{E}$ to $\mathrm{F}$, but by the time emergence began in May, $67 \%$ of the population were still in the penultimate and antepenultimate larval instars, indicating considerable lack of synchrony in the cohort. By June $86 \%$ of the cohort had moved to the final instar and by July most individuals had emerged and cohort 1 made up only $7 \%$ of the total larval population.

TABLE 3. Chi-square tests to compare the distribution of individuals across instar groups $\mathrm{C}$ to $\mathrm{F}$ between consecutive pairs of months (groups $\mathrm{E}$ and $\mathrm{F}$ were amalgamated and all $\chi^{2}-$ statistics were distributed with 1 d.f.).

\begin{tabular}{lcc}
\hline Pair of months & $\chi^{2}$ & $p$ \\
\hline October versus November & 9.63 & 0.002 \\
November versus January & 2.87 & 0.09 \\
January versus February & 0.77 & 0.38 \\
February versus March & 1.29 & 0.257 \\
March versus May & 20.81 & $<0.001$ \\
May versus June & 29.74 & $<0.001$ \\
June versus July & 54.67 & $<0.001$ \\
July versus August & 18.72 & $<0.001$ \\
August versus September & 11.03 & $<0.001$ \\
\hline
\end{tabular}


TABLE 4. T-tests for differences in mean head width between male (m) and female (f) C. mercuriale larvae in instar groups $\mathrm{D}$ to $\mathrm{F}$ ( $*$ t-test which does not assume equal variances).

\begin{tabular}{lrrccrcc}
\hline Instar group & $n_{m}$ & $n_{f}$ & $\begin{array}{c}\text { mean }_{\mathrm{m}} \pm \text { s.e. } \\
(\mathrm{mm})\end{array}$ & $\begin{array}{c}\text { mean }_{\mathrm{f}} \pm \text { s.e. } \\
(\mathrm{mm})\end{array}$ & $t$ & d.f. & $p$ \\
\hline $\mathrm{D}^{*}$ & 148 & 125 & $2.42 \pm 0$ & $2.42 \pm 2$ & -5.93 & 268.8 & $<0.001$ \\
$\mathrm{E}$ & 94 & 118 & $2.42 \pm 1$ & $2.42 \pm 3$ & -6.67 & 210 & $<0.001$ \\
$\mathrm{~F}$ & 44 & 39 & $3.46 \pm 0.02$ & $3.51 \pm 0.02$ & -2.39 & 81 & 0.0095 \\
\hline
\end{tabular}

First year larvae in Cohort 2 overwintered in a range of instar groups from $\mathrm{A}$ to $\mathrm{C}$ (from instars 2 to 10 ). Growth resumed in May and by June most individuals had entered instar group C. By September all the cohort had entered instar groups D (79\% of cohort), E (15\% of cohort) and F ( $7 \%$ of cohort).

Cohort 3 appeared in early June. Given that the incubation period in captivity is around three weeks (and hatch periods in the field are usually longer), this suggests that oviposition must have started in mid May. Between June and September cohort 3 passed rapidly through instar groups A, B (99\% of cohort in July) and C (83\% of cohort in September). This is consistent with the lack of egg diapause in C. mercuriale.

\section{Size structure of larval populations}

The degree of size separation or overlap between cohorts determines the potential for intraspecific predation or competition. This can be expressed as a ratio of the body of the largest larval groups to that of the smallest co-occurring group (Wissinger, 1988a). In C. mercuriale the ratio of mean head width of instar groups $A$ and $F$ ranged from 1.65 ( $\mathrm{Jan})$ to 6.16 (May) with a mean of 4.89 .

The variation in larval size dimensions was compared between C. mercuriale, a "summer" species (sensu Corbet, 1954) and P. nymphula, a "spring" species. The residuals from a regression of head width on hind tibia length for C. mercuriale showed significantly more variation than those derived from the same regression for $P$. nymphula (Levene's test statistic $=6.71, p=0.010, \sigma_{c m}=$ $0.1351, n=1195, \sigma_{p n}=0.0945, n=116$ ). Coefficients of variation $(V)$ in head width were calculated within instar groups (using the same groups as those found in $C$. mercuriale). These indicated that $C$. mercuriale was more variable in size than $P$. nymphula within instar groups B to $\mathrm{E}$ (instar group $\mathrm{A}-V_{c m}=17.6, n=71, V_{p n}=31.1, n=$ 14 ; instar group B $-V_{c m}=14.2, n=199, V_{p n}=9.7, n=31$; instar group $\mathrm{C}-V_{c m}=15.1, n=351, V_{p n}=5.5, n=32$; instar group D $-V_{c m}=6.5, n=273, V_{p n}=3.9, n=19$; instar group $\left.\mathrm{E}-V_{c m}=4.8, n=314, V_{p n}=2.0, n=4\right)$.

\section{Larval sex ratios and sexual size dimorphism in $C$. mercuriale}

Since individuals could only be sexed at head widths greater than or equal to $1.7 \mathrm{~mm}$, sex ratio was not examined in instar groups A, B and C. Sex ratio only differs from unity in C. mercuriale for instar $\mathrm{E}$ (penultimate instar) in which there is a significant excess of females (instar D - $134: 140$ (males : females), $\chi^{2}=0.09, p=$ 0.76 ; instar $\mathrm{E}-90: 122, \chi^{2}=4.53, p=0.03$; instar $\mathrm{F}-46$
$: 37, \chi^{2}=0.77, p=0.38$ ). For $P$. nymphula, there is no evidence that the sex ratio differs from unity, though samples sizes are low (instar $8-12: 4$ (males : females), $\chi^{2}=$ 3.06, $p=0.08$; instar $10-13: 14, \chi^{2}=0.00, p=1.00$; instar $\left.11-10: 7, \chi^{2}=0.24, p=0.63\right)$. Females of $C$. mercuriale were significantly larger than males in head width and tibia length for instars D to F (Table 4).

\section{CONCLUSIONS AND DISCUSSION}

\section{Voltinism and growth period}

At Glan-yr-afon Uchaf, Coenagrion mercuriale exhibits semi-voltine development consistent with a previous study at four British sites (Corbet, 1957a). Although most mid-european populations (such as those in Baden-Württemburg) also exhibit semi-voltine development (Sternberg et al., 1999), development was completed in one year when industrial cooling waters increased the water temperature (Thelen, 1992). This suggests that voltinism is a plastic trait in C. mercuriale and probably varies across regions depending on temperature and productivity of the habitat. Regional variation in voltinism in other odonates has been attributed to a variety of factors including latitude (Thompson, 1978b), temperature (Leggott \& Pritchard, 1985) and increased larval density (Banks \& Thompson, 1978b). Few odonates show genetic adaptation to temperatures (i.e. they retain plasticity in developmental traits) in the temperate zone, despite being insects of tropical origin (Leggott \& Pritchard, 1985). For example, individuals from three populations of Argia vivida from habitats with different thermal regimes showed similar rates of egg and larval development when reared at constant temperature. Whilst this lack of adaptation allows plasticity in response to environmental change, it may also limit the degree to which odonates (including $C$. mercuriale) have expanded into northern temperate regions.

Consistent with its semi-voltine development, C. mercuriale has a short growth period in Britain. The lack of significant changes in the distribution of individuals across instar groups between November and March suggests that no larval growth occurred in this part of the year, probably because some minimum temperature threshold for development was not attained during this period. Lower temperature thresholds for growth have been identified in a range of other temperate odonate species (e.g. $10-12^{\circ} \mathrm{C}$ for Coenagrion puella (Waringer, 1984); $8^{\circ} \mathrm{C}$ for Ischnura elegans (Thompson, 1978b); $12^{\circ} \mathrm{C}$ for Lestes disjunctus (Duffy, 1994); $11.3^{\circ} \mathrm{C}$ for Argia vivida (Leggott \& Pritchard, 1985) and may be caused proximately by the profound effect of temperature 
on activity (and thus the availability) of prey, and on the feeding rate of invertebrate predators increasing attack rate and decreasing handling time (Thompson, 1978b).

Within mainland Europe, the distribution of C. mercuriale is found between the $20^{\circ} \mathrm{C}$ annual isotherm in the south and the $10^{\circ} \mathrm{C}$ annual isotherm in the north (Stenberg et al., 1999). As well as limiting the latitude occupied by $C$. mercuriale, minimum winter temperature requirements for larval growth may partly determine microhabitat use in this species. Across its biotopes (both heathland and chalkstreams) in both Britain and Europe, the species occupies shallow, sun-exposed, permanently flowing water bodies (close to springs or ground-water) with relatively high minimum winter temperatures (Purse \& Thompson, in prep.; Buchwald, 1983; Buchwald, 1989; Buchwald, 1994; Sternberg et al., 1999).

\section{Location of diapause}

This study confirmed that there is no diapause in the egg stage of C. mercuriale (cf. Corbet, 1957a) since recently-hatched larvae appeared in June 2000 (and passed rapidly through instar groups A to C before September). In odonates, Corbet (1954a) distinguished between populations that overwinter (and diapause) in the final instar and have a closely synchronised and often early emergence ("spring" species) and those that overwinter in one or more earlier stadia, have less synchronised emergence and emerge later ("summer species"). Thus, the range of instars in which $2^{\text {nd }}$ year $C$. mercuriale larvae overwinter (i.e. the antepenultimate, penultimate and final instars) accounts for the asynchronous emergence curve of this species. Considerable asynchrony is evident in the $2^{\text {nd }}$ year group in May when, although some individuals had emerged, $67 \%$ of cohort 1 remained in the antepenultimate and penultimate instars. In a previous study, Corbet (1957a) found that $50 \%$ of the $2^{\text {nd }}$ year group had not entered the final instar by the time metamorphosis began.

When growth resumed in the $2^{\text {nd }}$ year group in spring, individuals passed rapidly from the antepenultimate to the penultimate instar and from the penultimate to the final instar (emergence beginning in May). If there were a rising series of lower temperature thresholds for entry into successive larval instars ( $c f$. Corbet, 1957a), transitions from the penultimate to the final instar would have occurred after transitions between the ante-penultimate and the penultimate instars. Thus, this study indicates that mechanism of seasonal regulation in C. mercuriale does not consist of a rising series of such thresholds. There may indeed be a higher temperature threshold for emergence from the final instar than for the preceding two larval moults. The delayed appearance of the adult stage may be due to the low proportion of the cohort that overwinter in the final instar (around 4\%). The data are not inconsistent with the existence of a facultative diapause in the penultimate instar in autumn. This could be induced by decreasing photoperiod such that larvae entering the penultimate instar in the autumn would tend to remain there for winter but in March and April, antepenultimate instar larvae would pass rapidly through the penultimate and final instars. A laboratory investigation of the effect of temperature and photoperiod on diapause ( $c f$. Lutz, 1974) in this species would be pertinent.

\section{Size structure of larval populations}

Voltinism affects the size structure of the population and therefore the type and intensity of population interactions (such as competition and predation) that can occur in different stages (Butler, 1984). In semivoltine populations, second year individuals co-occur with first year conspecifics. Wissinger (1988a) found that for two species of libellulids (Libellula lydia and L. luctuosa) some intraspecific predation always occurred when co-existing larvae differed by two or more instars. This predation increased in intensity as a function of the size difference between instars. In C. mercuriale, in most months, instar groups $\mathrm{A}$ and $\mathrm{B}$ coexisted with groups $\mathrm{D}$ to $\mathrm{F}$ thus there was at least two instars difference between the smallest and largest groups. The ratio of body size between coexisting cohorts ranged from 1.65 to 6.16 . This is similar to the range of ratios for odonates in which intraspecific predation has been found to occur (e.g. Libellula lydia; 3.0-11.8, L. luctuosa; 1.6-6.9, E. cynosura 1.0-2.4). Although there is the potential for intraspecific predation, within larval populations of C. mercuriale, there are several zygopterans in which it does not occur despite this potential (e.g. P. nymphula, Lawton, 1970a; I. elegans, Thompson, 1978a). No remains of C. mercuriale larvae were found in a limited sample of prey obtained from faecal pellets of C. mercuriale (Harris, 2000). Even if cannibalism is rare Gribbin \& Thompson (1990) found that interference suffered by small instars in the presence of large conspecifics resulted in reduced growth rates, doubled mean development time and reduced mean head widths over the period of one instar.

One consequence of interference competition may be spatial separation of large and small instars between different microhabitats. The winter disappearance of small instar groups observed in this study has been taken as indicative of such differential habitat use in a range of univoltine (Johannsson, 1978) and semivoltine (Corbet, 1957b; Lawton, 1970b; Macan, 1964) species. For example Anax imperator hatches in Potamogeton, moves to Litorella for the first year of larval development and then to Hypericum for the second year (Corbet, 1957b). However, both in this study and in a European study (Thelen, 1992), larvae of all instars of $C$. mercuriale were found in the perennial plant substrate throughout the year and no larvae were found in the peat layer on the base of the stream. Therefore spatial separation may be achieved by large and small instars occupying different portions of the water column rather than by separation into different microhabitats. Small instars probably retreat further towards the base of the submergent vegetation (cf. $P$. nymphula Bennett \& Mill (1993); Lawton (1970a)).

The larval population of $C$. mercuriale shows more variation in size dimensions than that of $P$. nymphula, both within the whole cohort and when divided into the same instar groups. C. mercuriale has a long, asynchronous emergence (Purse \& Thompson, submitted) whilst 
adult emergence, mating and oviposition are wellsynchronised in P. nymphula (Bennett \& Mill, 1993; Corbet \& Harvey, 1989; Gribbin \& Thompson, 1991; Lawton, 1970b). Thus the length of the oviposition and hatch periods will be greater for $C$. mercuriale than for $P$. nymphula, producing broader larval size distributions in the former species even within year classes (Johnson, 1991).

\section{Larval sex ratios and sexual size dimorphism}

As with many other invertebrates, the sex determination mechanism in odonates predicts a sex ratio of unity in the zygote (Kiauta, 1969). Thus any imbalances in sex ratio at emergence can be attributed to differential mortality of eggs or larvae which may arise due to sex-linked differences in form, activity or response to environmental factors. In common with other zygopterans (Corbet \& Hoess, 1998), an excess of males was found at emergence for $C$. mercuriale (Purse \& Thompson, submitted). Size selective predation on larger female larvae has been postulated as a mechanism by which mortality could have a disproportionate effect on females. It has been shown to operate when the predator is given a choice of instars which vary widely in size e.g. Ischnura verticalis by the pumpkin seed sunfish, Lepomis gibbosus (Dixon \& Baker, 1988). However, whilst female $C$. mercuriale larvae were significantly larger than males for the last three larval instars, the sex ratio in these instars was not male-biased - consistent with that found in other larval zygopterans (Baker et al., 1992; Duffy, 1994; Garrison \& Hafernik, 1981; Lawton, 1972; Pickup et al., 1984). Dimorphism may not have produced size selective predation since the differences in body dimensions between males and females were small despite their significance and may not be detectable by predators. Instead, Baker et al. (1992) having found sex-linked differences in activity and development rate of late instar larvae in I. verticalis, suggested that higher predation pressure on the more actively foraging sex may produce biased sex ratios. If sex-linked differences in activity or development arise only in late instar larvae, it may be difficult to detect differences in sex ratio before emergence in odonates.

In conclusion, Coenagrion mercuriale is semi-voltine and growth is prevented in winter in Britain where it is on the northern edge of its range. A facultative autumnal diapause in the penultimate instar is the most likely mode of seasonal regulation in this species. The broad size distribution of larvae within and between cohorts produced by this growth pattern may lead to intraspecific interference that may further increase mortality or decrease growth rates of larvae in edge-of-range populations.

ACKNOWLEDGEMENTS. We thank the Countryside Council for Wales for permission to work at Glan-yr-afon Uchaf, Mynydd Preseli. BVP was supported by a Studentship funded by the Environment Agency, English Nature and the Countryside Council for Wales and the work was carried out under licence from the Countryside Council for Wales.

\section{REFERENCES}

BAKER R.L. 1986: Developmental stages and the analysis of zygopteran life histories. J. Freshwater Ecol. 3: 325-332.

Baker R.L., Forbes M.R.L. \& Proctor H.C. 1992: Sexual differences in development and behaviour of larval Ischnura verticalis (Odonata: Coenagrionidae). Can. J. Zool. 70: 1161-1165.

BANKs M.J. 1985: Population Dynamics and Lifetime Reproductive Success of Damselflies. Unpublished PhD thesis, University of Liverpool, $259 \mathrm{pp}$.

Banks M.J., \& Thompson D.J. 1987: Regulation of damselfly populations: the effects of larval density on larval survival, development rate and size in the field. Freshwater Biol. 17: 357-365.

BENKE A.C. 1970: A method for comparing individual growth rates of aquatic insects with special reference to the Odonata. Ecology 51: 328-331.

Benke A.C. \& Benke S.S. 1975: Comparative dynamics and life histories of co-existing dragonfly populations. Ecology 56: 302-317.

Bennett S. \& Mill P.J. 1993: Larval development and emergence in Pyrrhosoma nymphula (Sulzer) (Zygoptera: Coenagrionidae). Odonatologica 22:133-145.

BuchWALD R. 1983: Kalkquellmoore und Kalkquellsumpfe als Lebensraum gefahrdeter Libellenarten im westlichen Bodenseeraum. Telma 13: 91-98.

Buchwald R. 1989: Die Bedeutung der Vegetation fur die Habitatbindung einiger Libellenarten der Quellmoore und Fliessgewasser. Phytocoenologia 17: 307-448.

Bucrwald R. 1994: Zur Bedeutung der Artenzusammensetzung und Struktur von Fliessgewasser-Vegetation fur die Libellenart Coenagrion mercuriale mit Bemerkungen zur Untersuchungsmethodik. Ber. D. Reinh.-Tuxen-Ges. Hannover 6 : 61-81.

Butler M.G. 1984: The life history of aquatic insects. In Rush V.H. \& Rosenberg D.M. (eds): The Ecology of Aquatic Insects. Praeger, New York, pp. 24-55.

CARCHINI G. 1983: A key to Italian Odonate larvae. Societas Internationalis Odonatologica Rapid Communications (Supplements. 1: $100 \mathrm{pp}$.

Corbet P.S. 1954: Seasonal regulation in dragonflies. Nature 174: 655,777 .

Corbet P.S. 1955: The larval stages of Coenagrion mercuriale (Charp.) (Odonata: Coenagrionidae). Proc. Roy. Entomol. Soc. Lond. 30: 115-126.

CoRbet P.S. 1957a: The life histories of two summer species of dragonfly (Odonata: Coenagrionidae). Proc. Zool. Soc. Lond. 128: 403-418.

CoRbet P.S. 1957b: The life-history of the emperor dragonfly Anax imperator Leach (Odonata: Aeshnidae). J. Anim. Ecol. 26: $1-69$.

Corbet P.S. 1980: Biology of Odonata. Annu. Rev. Entomol. 25 : 189-217.

Corbet P.S. \& Harvey I.F. 1989: Seasonal regulation in Pyrrhosoma nymphula (Sulzer) (Zygoptera: Coenagrionidae) I. Seasonal development in nature. Odonatologica 18:133-145.

Corbet P.S. \& Hoess R. 1998: Sex ratio of Odonata at emergence. Int. J. Odonatol. 1: 99-118.

DIXON S.M. \& BAKER R.L. 1988: Effects of size on predation risk, behavioural response to fish, and costs of reduced feeding in larval Ischnura verticalis (Coenagrionidae: Odonata). Oecologia 76: 200-205.

DownING J.A. 1984: Sampling the benthos dwelling on aquatic macrophytes. In Downing J.A. \& Rigler F.H. (eds): A Manual on Methods for the Assessment of Secondary Productivity in 
Fresh Waters. Blackwell Scientific Publications, Oxford, 358 pp.

DuFFY W.G. 1994: Demographics of Lestes disjunctus (Odonata: Zygoptera) in a riverine wetland. Can. J. Zool. 72: 910-917.

Edmonson W.T. \& WindBerg G.G. 1971: A Manual on Methods for the Assessment of Secondary Productivity in Freshwaters. Blackwells, Oxford, $358 \mathrm{pp}$.

Gardner A.E. \& MacNeill N. 1950: The life-history of Pyrrhosoma nymphula (Sulzer) (Odonata). Entomologist's Gazette 1: $163-182$.

GaRRISON R.W. \& HAFERNIK J.E. 1981: Population structure of the rare damselfly Ischnura gemina (Kennedy) (Odonata: Coenagrionidae). Oecologia 48: 377-384.

GRAND D. 1996: Coenagrion mercuriale (Charpentier, 1840). In van Helsdingen P.J., Willemse L. \& Speight M.C.D. (eds): Background Information on Invertebrates of the Habitats Directive and the Bern Convention - Part II: Mantodea, Odonata, Orthoptera, and Arachnida, Vol. 80. Council of Europe Publishing, Strasbourg, $396 \mathrm{pp}$.

GribBin S.D. \& Thompson D.J. 1990: Asymmetric intraspecific competition among larvae of the damselfly Ischnura elegans (Zygoptera: Coenagrionidae). Ecol. Entomol. 15: 37-42.

GribBIN S.D. \& Thompson D.J. 1991: Emergence of the damselfly Pyrrhosoma nymphula (Sulzer) (Zygoptera: Coenagrionidae) from two adjacent ponds in Northern England. Hydrobiologia 209: 123-131.

HaRrIs J. 2000: So you Want to be a Detective? The Diet of the Southern Damselfly (Coenagrion mercuriale). Unpublished BSc thesis, University of Liverpool, $79 \mathrm{pp}$.

HMSO 1995: Biodiversity: The UK Action Plan.

Johannsson O.E. 1978: Co-existence of larval Zygoptera (Odonata) common to the Norfolk Broads (U.K.). Oecologia 32: 303-321.

JoHnson D.M. 1991: Behavioural ecology of larval dragonflies and damselflies. TREE 6: 8-13.

KiAUTA B. 1969: Sex chromosomes and sex determining mechanisms in Odonata, with a review of the cytological conditions in the family Gomphidae, and references to the karyotypic evolution of the order. Genetica 40:127-157.

Krishnaraj R. \& Pritchard G. 1995: The influence of larval size, temperature, and components of the functional response to prey density on growth rates of the dragonflies Lestes disjunctus and Coenagrion resolutum (Insecta: Odonata). Can.J. Zool. 73: 1672-1680.

KVARNEMO C. \& AHNESJo I. 1996: The dynamics of operational sex ratios and competition for mates. TREE 11: 404-408.

LAWTON J.H. 1970a: Feeding and food energy assimilation in larvae of the damselfly Pyrrhosoma nymphula (Sulz.) (Odonata: Zygoptera). J. Anim. Ecol. 39: 669-689.

LAWTON J.H. 1970b. A population study on larvae of the damselfly Pyrrhosoma nymphula (Sulzer) (Odonata: Zygoptera). Hydrobiologia 36: 33-52.

LAWTON J.H. 1972: Sex ratio in Odonata larvae, with particular reference to the Zygoptera. Odonatologica 1:209-219.

Leggott M. \& Pritchard G. 1985: The effect of temperature on rate of egg and larval development in populations of Argia vivida Hagen (Odonata: Coenagrionidae) from habitats with different thermal regimes. Can. J. Zool. 63: 2578-2582.

Lutz P.E. 1974: Effects of temperature and photoperiod on larval development in Tetragoneuria cynosura (Odonata: Libellulidae). Ecology 55: 370-377.

MACAn T.T. 1964: The Odonata of a moorland fishpond. Int. Rev. Ges. Hydrobiol. 49: 325-360.

MAY M.L. 1978. Thermal adaptations of dragonflies. Odonatologica 7: 27-47.

Pickup J. \& Thompson D.J. 1984: The effects of prey density and temperature on development of larvae of the damselfly Lestes sponsa (Hans.) (Zygoptera: Lestidae). Advances in Odonatology 2:169-176.

Pickup J., Thompson D.J. \& Lawton J.H. 1984: The life-history of Lestes sponsa (Hansemann): Larval growth (Zygoptera: Lestidae). Odonatologica 13:451-459.

Purse B.V. \& Thompson D.J. (submitted): Emergence pattern of the damselflies (Odonata: Coenagrionidae), Coenagrion mercuriale (Charpentier) and Ceriagrion tenellum (Villers), two species at their northern range margin. Eur. J. Entomol.

Purse B.V. \& Thompson D.J. (in prep.): Status and broad scale habitat use of the Southern Damselfly Coenagrion mercuriale (Charpentier) (Odonata: Coenagrionidae) in Britain.

Samways M.J. 1994: Insect Conservation Biology. Chapman \& Hall, London, 358 pp.

Sternderg K. 1994. Niche specialization in dragonflies. Advances in Odonatology 6: 177-198.

Sternberg K., Buchinald R. \& Roske W. 1999: Coenagrion mercuriale (Charpentier, 1840) - Helm Azurjungfer. In Sternberg K. \& Buchwald R. (eds): The Dragonflies of Baden Wurttemburg. Eugen Ulmer Press, Stuttgart, 468 pp.

Tauber M.J., Tauber C.A. \& Masaki S. 1986: Seasonal Adaptation of Insects. Oxford University Press, New York, 416 pp.

THelen C. 1992: Untersuchung zum Larvenhabitat und zum Entwicklungszyklus der Helmazurjungfer (Coenagrion mercuriale, Zygoptera: Odonata) an zwei verchiedenen Gewassern der Freiburger Bucht. Thesis, Universität Freiburg.

Thomas J.A., Rose R.J., Clarke R.T., Thomas C.D. \& Webb N.R. 1999: Intraspecific variation in habitat availability among ectothermic animals near their climatic limits and their centres of range. Funct. Ecol. 13: 55-64.

THOMPSON D.J. 1978a: The natural prey of larvae of the damselfly, Ischnura elegans (Odonata: Zygoptera). Freshwater Biol. 8: $377-384$.

Thompson D.J. 1978b: Towards a realistic predator-prey model: the effect of temperature on the functional response and life history of larvae of the damselfly, Ischnura elegans. J. Anim. Ecol. 47: 757-767.

WISSINGER S.A. 1988a: Life history and size structure of larval dragonfly populations. J. N. Am. Benthol. Soc. 7:13-28.

WISSINGER S.A. 1988b: Spatial distribution, life history and estimates of survivorship in a fourteen-species assemblage of larval dragonflies. Freshwater Biol. 20: 329-340.

Received October 5, 2001; revised January 9, 2002; accepted January 25, 2002 